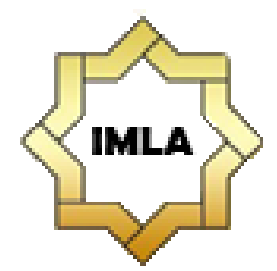

\author{
Al-Ta'rib \\ Jurnal Ilmiah Program Studi Pendidikan Bahasa Arab \\ IAIN Palangka Raya \\ Vol. 8, No. 1, June 2020, 77-90 \\ p-ISSN 2354-5887 | e-ISSN 2655-5867
}

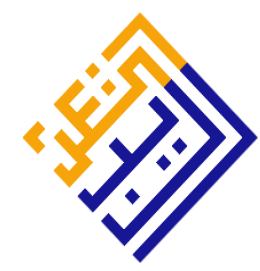

\title{
INSTAGRAM: ALTERNATIF MEDIA DALAM PENGEMBANGAN MAHARAH AL-KITABAH
}

\author{
Noor Amalina Audina', Muassomah'², \\ 1,2Universitas Islam Negeri Maulana Malik Ibrahim Malang, Indonesia \\ E-mail: nooramalinaaudina@yahoo.com
}

\begin{abstract}
This study aims to show that Instagram, which has only been popular for posting photos or videos, is very effective as a medium of al-Kitabah learning and can increase the ability of the students in al-Kitabah Maharah. In addition, it shows positive and negative responses of students to the use of Instagram as al kitabah maharah learning media. The study uses a qualitative descriptive approach and data and information were collected by using observation, interviews and documentation. Data analysis techniques used Miles and Huberman models, namely data reduction, data presentation and data verification. The results of this study indicate that Instagram is one of the social media that strongly supports and motivates students to create and innovate in writing without being limited to place and time. Based on the results of the questionnaire, it was obtained a very positive response from 21 students that all students agreed with the use of Instagram as a medium for learning alKitabah maharah. Students give positive responses because they are flexible, not limited in time, learning is more varied and students are more active and creative. As for the negative responses of students needing an internet connection, teachers do not control directly. Researchers hope that with this study, the teachers can use the Instagram application as a medium for learning Arabic, so students can wisely utilize social media.
\end{abstract}

Keywords: Instagram; Maharah Al Kitabah; Learning Media; Technology

\begin{abstract}
Abstrak
Penelitian ini bertujuan untuk menunjukkan bahwa Instagram yang selama ini hanya populer untuk memposting foto atau video sangat efektif digunakan sebagai media pembelajaran maharah al kitabah dan dapat meningkatkan kemampuan maharah al kitabah. selain itu menunjukkan tanggapan positif dan negative santri terhadap penggunaan Instagram sebagai media pembelajaran maharah al kitabah. Metode penelitian ini menggunakan pendekatan kualitatif dekskriptif data dan informasi dikumpulkan dengan menggunakan observasi, wawancara dan dokumentasi. Dan Teknik Analisis data menggunakan model miles dan Hubernam yaitu reduksi data, penyajian data dan verifikasi data. Hasil penelitian ini menunjukkan bahwa Instagram adalah salah satu media sosial yang sangat mendukung dan memotivasi santri untuk berkreasi dan berinovasi dalam menulis
\end{abstract}


tanpa terbatas tempat dan waktu. berdasarkan hasil angket tanggapan sangat positif dari 21 santri bahwa seluruh santri setuju dengan penggunaan Instagram sebagai media pembelajaran maharah al kitabah. Santri memberikan tanggapan positif karena fleksibel, tidak terbatas waktu, pembelajaran lebih bervariasi dan santri lebih aktif dan kreatif. Adapun tanggapan negatif santri membutuhkan koneksi internet, pengajar tidak mengontrol secara langsung. Peneliti berharap dengan adanya penelitian ini para pengajar bisa memanfaatkan aplikasi Instagram sebagai media pembelajaran bahasa Arab, agar siswa bisa dengan bijak memanfaatkan media sosial.

Kata Kunci: Instagram; Maharah Al Kitabah; Media Pembelajaran; Teknologi

\section{Pendahuluan}

Perkembangan zaman dari era revolusi industry 4.0 ke era society 5.0 merupakan perkembangan yang terelakkan. Perkembangan ini dilandasi oleh munculnya kekhawatiran bahwa era revolusi 4.0 berpotensi mendegradasi umat manusia mengingat era ini hanya fokus pada kecerdasan dalam mengembangkan teknologi tanpa dibarengi oleh pemberdayaan SDM. Maka dari itu, era society 5.0 hadir sebagai solusi dari kekhawatiran tersebut. era society 5.0 lahir untuk mengintegrasikan antara kehidupan dunia nyata dan dunia maya sehingga tidak terjadi adanya degradasi umat manusia (Deguchi et al., 2020).

Di era ini, perkembangan teknologi digital sejatinya semakin tidak terbendung. Berbagai macam smartphone dengan sistem operasi Android OS dan IOS terus diciptakan untuk menunjang mobilitas manusia baik di dunia Pendidikan, ekonomi, dan lain sebagainya. Begitu juga aplikasi-aplikasi media sosial yang tersedia di smartphone seperti Youtube, Facebook, Twitter, Instagram , Line, Whatapp, dan lain sebagainya telah akrab di kalangan manusia khususnya para remaja (Mubarak et al., 2020). Bahkan AlBantani dalam penelitiannya mengungkapkan bahwa para remaja (pelajar masa kini) bisa disebut dengan penduduk asli digital mengingat media sosial adalah sesuatu yang sangat dekat dan akrab dalam kehidupan sehari-hari mereka (A. Albantani et al., 2020). Pendapat ini juga diperkuat oleh Dermott yang menyatakan bahwa "stated that the digital natives grow up and are surrounded by technology and became accustomed to using new media throughout their daily lives" (Mc Dermott, 2013).

Berdasarkan hasil riset yang dilakukan Sekolah Tinggi Sandi Negara (STSN) Indonesia bekerjasama dengan Yahoo menunjukkan bahwa kalangan remaja usia 15-19 tahun mendominasi pengguna Internet di Indonesia sebanyak 64 \% (Aspari, 2016). Hal ini juga didukung oleh media Detik.com yang melaporkan bahwa sampai akhir 2018, pengguna aktif internet mencapai 1,8 miliar orang (Hidayat, n.d.). fenomena ini tentunya mendapatkan perhatian khusus oleh para peneliti di bidang pendidikan mengingat siapapun yang tidak menguasai ilmu pengetahuan dan teknologi maka posisinya akan termarginalkan dan terhempas pada globalisasi yang sarat dengan kompetisi (Haniah, 2014). Di sisi lain, Ahmadi menambahkan bahwa optimalisasi teknologi informasi dalam pelaksanaan pembelajaran sangat diperlukan untuk melahirkan suasana pembelajaran yang menarik, menyenangkan, dan tidak monoton (Ahmadi, 2014). 
Albantani mengungkapkan bahwa perkembangan teknologi seperti media sosial Youtube, Facebook dan Instagram dapat dijadikan sebagai media alternatif yang dapat digunakan oleh pendidik dalam pembelajaran bahasa Arab baik dari tingkatan siswa sekolah dasar, menengah hingga perguruan tinggi (A. M. Albantani, 2019). Media sosial terbukti dapat meningkatkan motivasi dan minat siswa dalam belajar serta memberikan fleksibelitas dalam proses pembelajaran karena tidak dibatasi oleh ruang dan waktu (Linur \& Mubarak, 2020). Hal ini selaras dengan pendapat Munir yang mengungkapkan bahwa keberhasilan pembelajaran bahasa Arab tidak hanya ditentukan oleh penyusunan materi yang baik, tetapi juga dipengaruhi oleh ketepatan memilih metode dan media yang digunakan untuk menunjang efektivitas dan efisiensi proses pembelajaran (Munir, 2016).

Salah satu media sosial yang populer dalam dunia Pendidikan adalah Instagram. Dalam penggunaannya, Instagram terbukti mampu meningkatkan motivasi peserta didik, dan mampu menghasilkan kemampuan keterampilan menulis (kitabah/writing) yang lebih baik (Anggraeni, 2017). Fakta ini juga didukung oleh penelitian Syukria yang menunjukkan bahwasa implementasi Project Based Learning (PJBL) dengan media Instagram dapat meningkatkan keterampilan menulis bahasa Arab para peserta didiknya. Perpaduan apik antara metode pembelajaran dan media kontemporer sangat layak untuk dilaksanakan dalam proses pembelajaran Bahasa. Melalu instagram, peserta didik dapat mengemukakan dan menggunakan teks interaksi transaksional tulis sederhana terkait tutur kata fasilitas umum atau bangunan sekolah, memperhatikan fungsi sosial, struktur teks, dan unsur kebahasaan yang benar sesuai dengan konteks dengan rasa ingin tahu, tanggung jawab, disiplin selama proses pembelajaran dan bersikap jujur serta pantang menyerah (Syukriya, 2019). Hal ini dibuktikan oleh penelitian (Khalitova \& Gimaletdinova, 2016) bahwa Aplikasi Instagram adalah media pembelajaran yang efektif untuk para remaja.

Salah satu pengajar di Pondok pesantren Al-Azhar Malang menggunakan media Instagram sebagai media pembelajaran maharah al kitabah. Pengunaan Instagram ini didasari oleh beberapa alasan, yaitu: Pertama, Santri berasumsi bahwa maharah al kitabah memiliki tingkat kesulitan tertinggi dalam pembelajaran bahasa Arab. Mereka cenderung mengalami kesulitan untuk mengeksplorasikan ide-ide mereka dalam bentuk tulisan. Kedua, dalam penguasaanya, maharah al kitabah membutuhkan skill yang menyeluruh baik kosakata ataupun grammar sehingga perlu adanya inovasi sebuah metode atau media yang efektif dan efisien sebagai penunjang ketercapaian tujuan dari pembelajaran maharah al kitabah. Ketiga, Instagram merupakan media yang sangat dekat dengan santri, mereka menggunakan media Instagram untuk mengeksplorasi ide atau pikiran mereka ke dalam sebuah foto atau video menggunakan bahasa Arab.

Penelitian ini bermaksud untuk mengeksplorasi lebih dalam tentang penggunaan media Instagram dalam pembelajaran maharah al kitabah yang diterapkan oleh satu pengajar di Pondok Pesantren Al-Azhar Malang. Penelitian ini menarik untuk dilakukan mengingat maharah al kitabah membutuhkan skill yang menyeluruh baik kosakata ataupun grammar dalam penguasaannya. Penelitian ini diharapkan dapat merespon terhadap kesulitan santri dalam aspek keterampilan menulis dengan benar sesuai kaidah bahasa Arab. Sejalan dengan itu, tujuan dari 
penelitian ini adalah untuk mendeskripsikan penggunaan Instagram dalam pembelajaran maharah al kitabah dan persrpsi santri mengenai penggunaan Instagram dalam maharah al kitabah.

\section{Metode}

Penelitian ini menggunakan penelitian kualitatif deskriptif. Penelitian ini dilakukan untuk mengeksplorasi penggunaan media Instagram dalam pembelajaran maharah Al Kitabah dan bagaimana persepsi santri mengenai penggunaan Instagram dalam maharah al kitabah. Tempat (place) penelitian ini di pondok pesantren Al Azhar Malang Jawa Timur. Adapun pelaku (actors) adalah pengajar dan 21 santri bahasa Arab ponpes Al Azhar Malang yang belajar menggunakan Instagram. Dan aktivitas (activity) adalah pembelajaran maharah al kitabah dengan menggunakan media sosial Instagram.

Pengumpulan data dalam penelitian ini dilakukan dengan teknik triangulasi yang terdiri dari observasi partisipatif, wawancara terbuka dan dokumentasi. Observasi dilakukan untuk pengamatan secara langsung ketika santri mengerjakan tugas yang telah diberikan, mengamati kendala-kendala yang dihadapi dan ekspresi santri secara langsung ketika menggunakan Instagram sebagai media pembelajaran di lapangan. Wawancara secara langsung kepada satu pengajar dan 3 santri yang mewakili perkelas. dokumen angket disebarkan ketiga kelas full time I berjumlah 7 santri, full time II berjumlah 7 santri dan full time III berjumlah 7 santri dengan total keseluruhan adalah 21 santri. sebagai instrument penguat untuk mengetahui persepsi santri.

Penelitian ini menggunakan teknik analisa data kualitatif dengan tahapan yang senada dengan Mills dan Hubbermans (Miles \& Huberman, 2009) yaitu: (1) reduksi data, untuk memilah data mentah yang dihasilkan dari observasi, wawancara dan dokumentasi. (2) penyajian data (display data) setelah data direduksi maka peneliti menyajikan data implementasi Instagram dalam pembelajaran maharah al kitabah, langkah-langkah penggunaan Instagram dalam pembelajaran maharah al kitabah dan persepsi santri terhadap penggunaan Instagram dalam pembelajaran maharah al kitabah. (3) Verifikasi (conclusion drawing/verification) setelah data disajikan peneliti menyimpulkan dari hasil reduksi data dan penyajian data hasil penelitian kemudian disimpulkan.

\section{Hasil dan Pembahasan}

Berdasarkan dari paparan data hasil observasi, wawancara dan dokumentasi yang ada di lapangan, peneliti akan membahas terkait dengan penggunaan media sosial Instagram dalam maharah al kitabah, yaitu: Implementasi Penggunaan Instagram dalam pembelajaran maharah al kitabah, langkah-langkah penggunaan Instagram dalam pembelajaran maharah al kitabah dan persepsi santri terhadap penggunaan Instagram.

\section{Implementasi Penggunaan Instagram Dalam Pembelajaran Maharah AI Kitabah}

Ada beberapa fitur didalam Instagram yang dapat digunakan dalam pembelajaran maharah al kitabah: 


\section{Feed Instagram}

Feed Instagram adalah fitur aplikai Instagram yang dapat digunakan untuk memposting foto atau video dengan durasi kurang lebih satu menit. Feed Instagram bersifat permanen, hanya akan hilang jika dihapus. Foto atau video yang diposting dapat diedit sesuai yang pengguna inginkan dan dapat menandai pengguna-pengguna lain. Feed Instagram inilah yang sering digunakan oleh para pengguna aktif Instagram. Salah satu fitur Instagram yang sering dijangkau oleh santri adalah feed Instagram. Dalam feed Instagram santri dapat menggunggah foto atau video disertai dengan caption yang dia inginkan. Feed Instagram Caption foto disinilah yang mengekplorasi bahasa santri menggunakan bahasa Arab. Dalam pembelajaran maharah al kitabah ada beberapa tingkatan cara pembelajaran dasar seperti menulis kata, Menyusun kata menjadi kalimat, Menyusun kata menjadi kalimat, atau menyusun kata-kata yang diacak menjadi kalimat yang benar hingga menyusun kalimat menjadi paragraph dan beberapa paragraph menjadi sebuah cerita. Dalam pembelajaran maharah al kitabah semua disesuaikan dengan kognitif santri (Sa'diyah, 2019).

\section{Instagram Story}

Instagram story adalah salah satu fitur yang digunakan untuk memposting foto atau video dengan durasi kurang lebih 15 detik. Instagram story hanya bersifat sementara dengan jangka waktu 24 jam, setelah 24 jam postingan akan hilang dengan sendirinya jika tidak dihapus (Romney \& Johnson, 2020). Instagram story sangat digemari oleh para remaja sekarang seperti pelajar, mahasiswa dan terkhusus santri Al Azhar Malang. Penggunaan Instagram story dalam pembelajaran maharah al kitabah bisa digunakan dengan cara seperti halnya santri mengupdate story mereka. Hanya saja perbedaan mendasarnya adalah story yang mereka buat harus menggunakan bahasa Arab, pemberian tugas kitabah dapat bervariasi seperti membuat kalimat sederhana, menerjemahkan paragraph atau teks, ataupun bercerita pendek dengan tema tertentu.

\section{Langkah-langkah penggunaan Instagram}

Sebelum masuk ke langkah-langkah penggunaan Instagram, pengajar mengungkapkan ada beberapa tahap-tahap yang harus diperhatikan dalam penggunaan Instagram dalam maharah al kitabah, yaitu:

\section{Preparing Aplikasi}

Pengajar harus memastikan terlebih dahulu setiap santri memiliki media Instagram dan akun Instagram. Kemudian menentukan fitur Instagram apa yang akan digunakan dalam pembelajaran. Menurut pengajar fitur yang menarik untuk digunakan dalam pembelajaran Maharah al kitabah adalah feed Instagram dan Instagram Story karena keduanya merupakan fitur Instagram yang sering dijangkau dan digemari oleh para santri.

\section{Introducing the Topic}

Tahap kedua yang harus di perhatikan pengajar memberikan tema yang akan menjadi tugas santri, sesuai dengan tema yang telah di ajarkan atau tema yang sedang dibahas. Karena dalam maaharah al kitabah ada beberapa tingkatan cara pembelajaran yaitu untuk kelas mubtadi, kelas mutawasith dan kelas mutaqoddim.

\section{Tasking (pemberian tugas)}

Sebelum tugas tersebut dikerjakan oleh santri, ini adalah tahap penting yang harus diperhatikan karena yang disampaikan pengajar sebegai tugas akan menjadi 
kunci inti dari penugasan. Dalam pemberian tugas ini harus disesuaikan dengan tingkat kemampuan bahasa santri karena hal ini berpengaruh dengan hasil atau capaian santri dalam kemampuan bahasa mereka. Baik dari segi materi, kesesuaian tugas, dan tingkat pencapaian santri merupakan komponen yang harus diperhatikan.

\section{Evaluating}

Tahap terakhir yang harus diperhatikan adalah evaluasi. Proses pembelajaran maharah al kitabah menggunakan media sosial Instagram bertujuan untuk mengetahui capaian yang ada pada santri dengan mengevaluasi penugasan tersebut.

\section{Gambar 1. \\ Tahap-tahap yang Perlu Diperhatikan dalam Penggunaan Instagram}

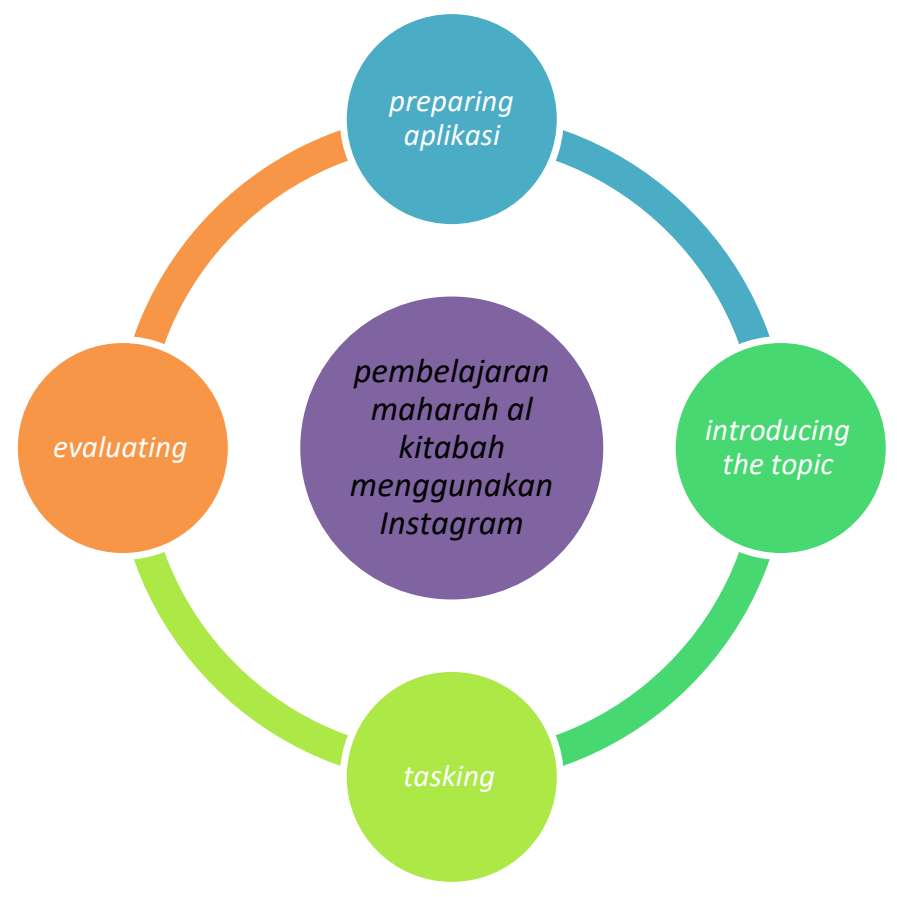

Berikut ini langkah-langkah penggunaan Instagram sebagai media pembelajaran maharah al kitabah: Pertama, pengajar memastikan semua santri memiliki Instagram; Kedua, pengajar menentukan fitur Instagram yang digunakan yaitu feed Instagram dan Instagram Story;

Ketiga, Pengajar menentukan tema (judul pembahasan) yang akan dikerjakan oleh santri. Disini, pengajar mengambil tiga tingkatan kelas dengan menggunakan Instagram: (1) untuk kelas mubtadi / Full Time I, pengajar memberikan tema sederhana Al-Al'wan (warna). (2) Untuk kelas mutawasith / Full Time II, pengajar memberikan tentang Tarwij Ma'had Al-Azhar Malang (promosi pondok Al Azhar Malang). (3) Untuk kelas mutaqoddimin / Full Time III, pengajar memberikan tema Wiqoyatu Kuruna Al-Mustajidi (pencegahan virus Corona).

Keempat, tasking (pemberian tugas). Dalam pemberian tugas pengajar menyesuaikan dengan tingkat kognitif dan kelas santri. (1) Untuk kelas mubtadi / 
Full Time I, pengajar menyampaikan kepada santri untuk menggunggah gambar atau video singkat di Instagram Story, kemudian menuliskan mufrodat sesuai gambar dan membuat kalimat sederhana dari tema Al-Al'wan (warna) materi di ambil dari buku Mufrodat yang digunakan di kelas Full Time I. (2) Untuk kelas mutawasith / Full Time II, pengajar menyampaikan kepada santri untuk menggunggah foto atau video yang menarik selama berada di Pondok Al-Azhar Malang. Kemudian menceritakan dengan cerita pendek dengan maksud mempromosikan pondok Al Azhar. (3) Untuk kelas mutaqoddimin / Full Time III, pengajar menyampaikan kepada santri untuk mengunggah foto terkait dengan judul diatas, berita yang sedang hangat dibicarakan yaitu terkait dengan virus corona. Santri menuliskan dengan bahasa Arab di feed Instagram.

Kemudian, pengajar menyepakati waktu bersama santri untuk pengumpulan tugas sesuai waktu yang telah ditentukan, dan setelah santri menulis caption tulisan dengan berbahasa Arab maka pengajar memberikan hastag yaitu \#belajarbahasaArabmudah \#ponpesalazharMalang \#fulltime1malang \#fulltime2malang \#fulltime3malang. Adapun tujuan untuk tingkatan kelas fulltime disesuaikan dengan tingkatan kelas masing-masing. Adapun hastag ini bertujuan untuk memudahkan pengumpulan tugas dan pengecekan tugas bagi pengajar untuk mengevaluasi nantinya.

Kelima, santri melaksanakan tugas yang diberikan oleh pengajar sesuai dengan perintah. Keenam, tahap pengumpulan tugas dan penilaian, pengajar melakukan pengecekkan tugas-tugas yang dikumpulkan santri melalui hastag yang sudah ditentukan dan mengecek apakah santri ada yang terlambat dalam mengumpulkan tugas, kemudian pengajar melakukan penilaian. Pengajar menyampaikan bahwa hasil tugas terbaik akan direpost oleh Instagram pondok pesantren al Azhar Malang. Adapun Evaluasi dalam maharah al kitabah dilihat dari beberapa aspek, yaitu: gaya bahasa, tata bahasa dan makna. (1) gaya bahasa santri dalam mengekspresiken ide, gagasan dan memberikan pendapat ketika menulis, (2) tata bahasa ketepatan menulis sesuai dengan kaidah nahwiyyah dan sharfiah dan ketepatan menggunakan tanda baca, (3) makna yang terkandung dalam tulisan harus berkaitan dengan tema yang sudah ditentukan. Selain evaluasi pada maharah al kitabah, pengajar juga menilai kreatifitas dan inovasi santri dalam menyajikan gambar atau foto yang mereka unggah di Instagram, hasil tugas yang baik akan di repost oleh akun pondok Al Azhar Malang.

Gambar 2.

\section{Evaluasi Pembelajaran Maharah Al Kitabah Menggunakan Instagram}

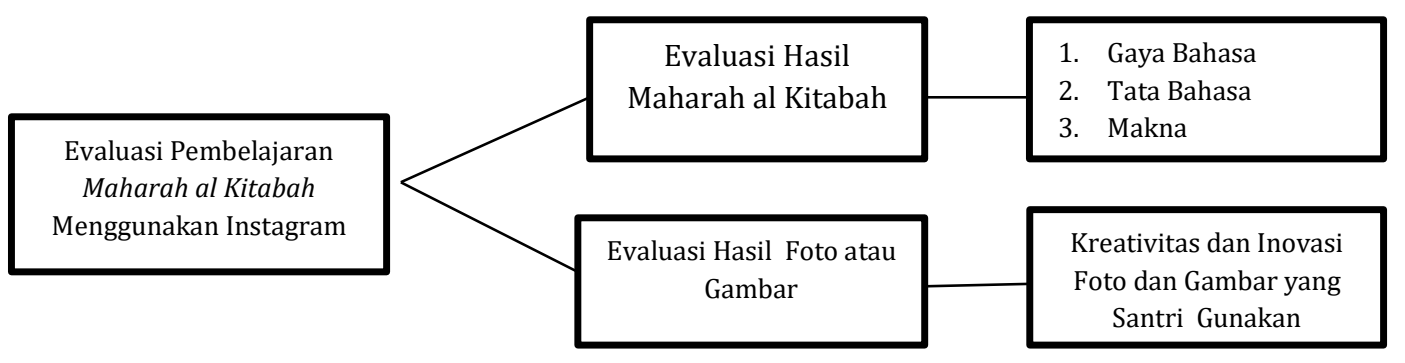


Dapat disimpulkan bahwa langkah-langkah penggunaan Instagram dalam pembelajaran maharah al kitabah terdiri dari: (1) menyiapkan aplikasi, (2) pengajar menentukan fitur Instagram yang digunakan bisa berupa feed Instagram atau Instagram Story, (3) pengajar menentukan tema, (4) pemberian tugas yang jelas oleh pengajar terkait tema, hastag dan penilaian, (5) pengumpulan tugas oleh santri di Instagram masing-masing, (6) evaluasi hasil dari pengajar. Dari langkahlangkah tersebut pengajar memiliki peran penting dalam pengarahan tugas agar santri bisa memahami dengan jelas apa yang akan mereka kerjakan. Adapun tematema pembelajaran bisa di ambil dari buku bahan Ajar yang sudah dipelajari. Dan dalam pembuatan tugas pengajar memberikan kebebasan kepada santri untuk berkreasi baik dalam memilih foto atau gambar, yang penting menarik dan sesuai dengan tema yang telah ditentukan. kitabah:

Berikut adalah hasil penggunaan Instagram dalam pembelajaran maharah al

\section{Gambar 3.}

\section{Hasil Penggunaan Instagram (Kelas Mubtadi' / Full Time I)}
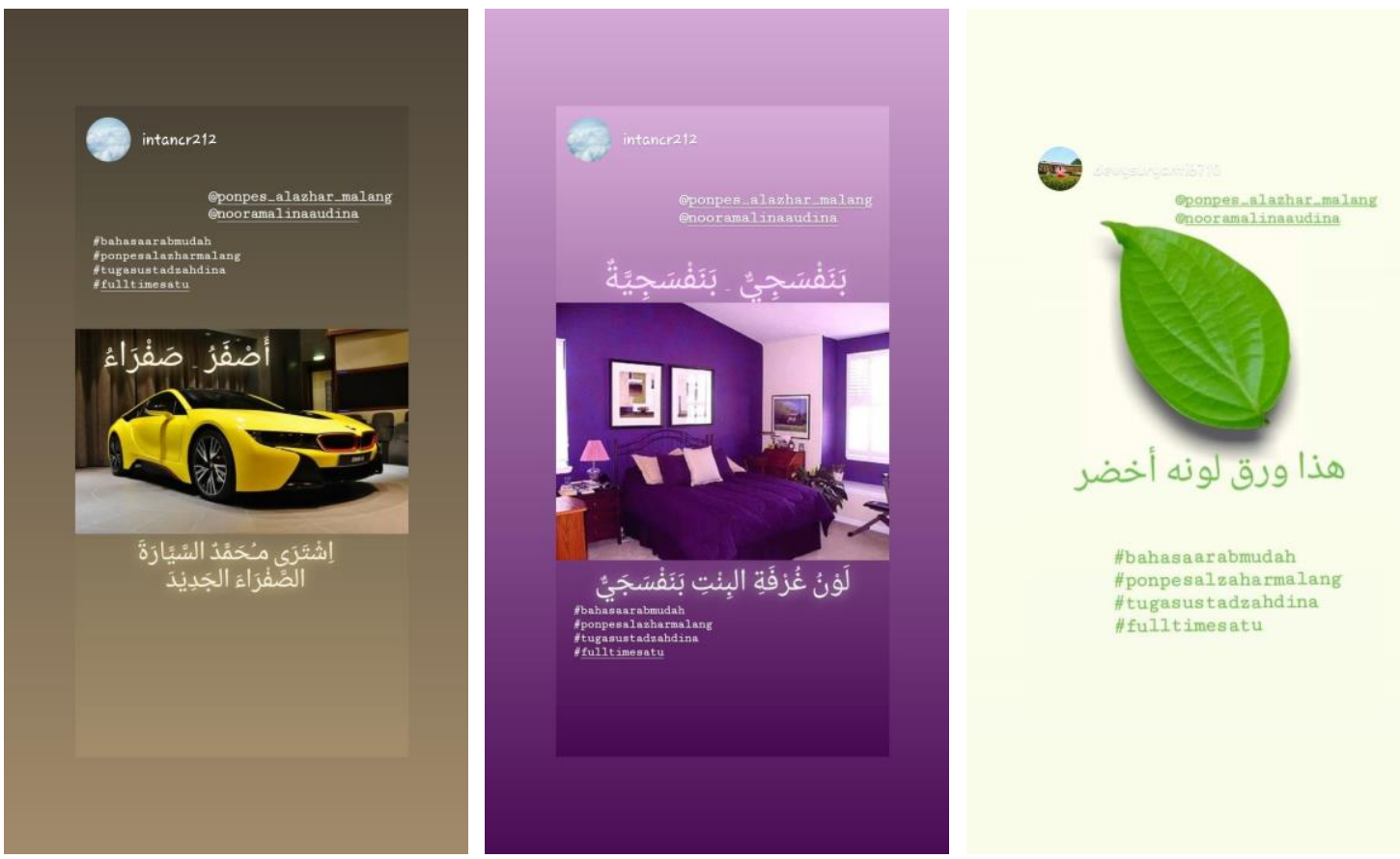

Gambar 3 merupakan hasil penggunaan Instagram pada pembelajaran maharah al kitabah dengan menggunakan fitur Instagram story di kelas dasar / full time I. pada contoh di atas adalah hasil dari dua santri dengan akun pribadi mereka yang bernama@intancr212 dan @dewisuryani. Pada gambar tersebut santri menggunggah foto yang menarik dan kreatif dengan tema Al-Al'wan (warna). kemudian santri membuat kalimat sederhana dari kosakata yang telah dipilih. 

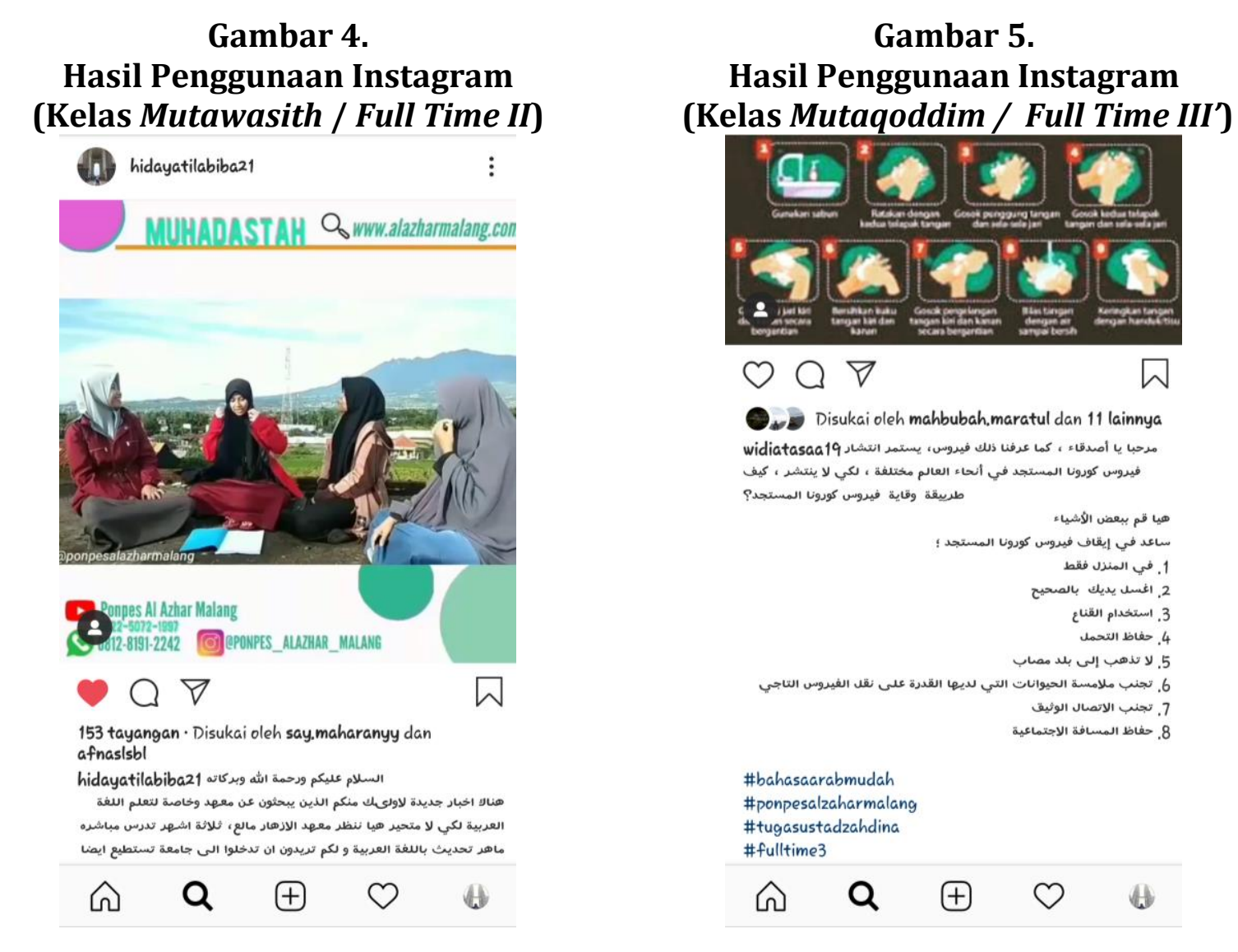

Gambar 4 merupakan hasil penggunaan Instagram pada pembelajaran maharah al kitabah dengan menggunakan fitur feed Instagram di kelas mutawassith / full time II. Pada gambar tersebut santri menggunggah video ketika kegiatan kebahasaan di Pondok Al-Azhar Malang yaitu halaqoh lughowiyyah. Karena tema yang telah ditentukan sebelumnya adalah Tarwij Mah'had Al Azhar Malang (promosi pondok Al Azhar Malang) maka santri mengunggah video yang menunjang daya tarik pembelajaran bahasa Arab di ponpes Al Azhar Malang dengan tema Tarwij Mah'had Al Azhar Malang (promosi pondok Al Azhar Malang). Pada video ini sudah ditayangkan 155 kali tayangan oleh para followers yang melihat akun IG @hidayatilabiba21. Pada tema ini santri diberikan kebebasan untuk membuat konsep tulisan selama tidak keluar dari tema yang ditentukan.

Gambar 5 merupakan hasil penggunaan Instagram dalam pembelajaran maharah al kitabah dari salah satu santri ponpes Al-Azhar Malang dengan pengguna akun Instagram bernama @widiyatasaa1 menggunakan fitur feed Instagram di kelas mutaqoddim / Full Time III postinganya sudah di like sebanyak 11 orang. Pada gambar tersebut santri diminta untuk mengunggah foto pencegahan virus corona karena tema yang berkaitan adalah Wiqoyatu Kurunal Mustajidi (pencegahan virus Corona). Untuk kelas mutaqoddim pengajar mengambil tema berita yang masih hangat dibicarakan kemudian santri mendeskripsikan tulisannya menggunakan bahasa Arab. 


\section{Persepsi Santri Terhadap Penggunaan Instagram Dalam Pembelajaran Maharah Al Kitabah}

Dalam hal ini peneliti juga mengumpulkan hasil responden sebanyak 21 orang santri yang sudah terkumpul menjadi satu kelas yaitu full time 1-3 melalui angket yang disebarkan via google form. Adapun soal angket terdiri dari 4 soal yaitu : satu soal dengan menggunkan skala likert yang mempunyai gradasi dari sangat setuju, setuju, tidak setuju dan sangat tidak setuju dan tiga soal menggunakan jawaban deskriptif. Peneiti mengkategorikan jawaban SS dan S sebagai tanggapan positif. Sedangkan jawaban TS dan STS sebagai tanggapan negatif.

Berikut adalah bentuk soal angket kepuasan mahasiswa mengenai penggunaan Instagram terhadap pembelajaran maharah al kitabah : Pertama, Bagaimana pendapat anda mengenai Instagram terhadap penggunaan pembelajaran maharah al kitabah ? Kedua, Berikan alasan anda terkait soal nomor 1 ! Ketiga, Apa kelebihan dari penggunaan Instagram pada pembelajaran maharah al kitabah? Keempat, Apa kekurangan dari penggunaan Instagram pada pembelajaran maharah al kitabah?

Berikut ini adalah diagram hasil tanggapan santri mengenai penggunaan Instagram pada pembelajaran maharah al kitabah :

\section{Gambar 6.}

\section{Diagram Hasil Angket Google Form Tanggapan Santri Penggunaan Instagram}

\section{Diagram Hasil Angket}

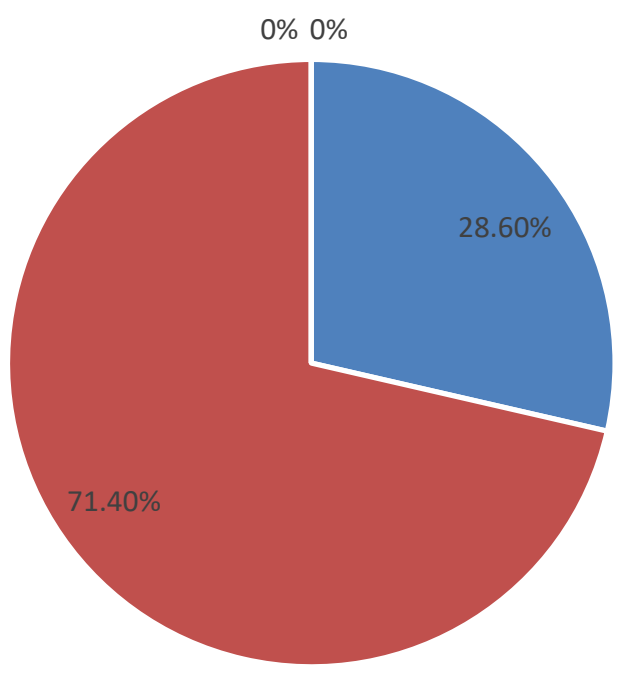

- Sangat Setuju (SS)

- Setuju (S)

- Tidak Setuju (TS)

- Sangat Tidak Setuju (STS)

Dari hasil diagram di atas dapat disimpulkan bahwa mahasiswa yang memberikan tanggapan sangat setuju (SS) ada enam orang santri dengan kalkulasi $(28,6 \%)$ adapun tanggapan setuju (S) ada lima belas orang santri dengan kalkulasi $(71,4 \%)$ adapun tidak setuju (TS) dan sangat tidak setuju (STS) tidak ada seorangpun dengan kalkulasi (0\%). Dari semua hasil tanggapan 21 santri, seluruh santri memberikan tanggapan positif terhadap penggunaan Instagram dalam 
pembelajaran maharah al kitabah. Berikut kesimpulan hasil tanggapan santri terkait kelebihan dan kekurangan penggunaan Instagram dalam pembelajaran maharah al kitabah.

\section{Kelebihan Instagram sebagai media pembelajaran maharah al kitabah}

Hasil penelitian ini menunjukkan beberapa tanggapan positif santri berdasarkan hasil angket yang telah di isi oleh 21 santri ponpes Al Azhar Malang menunjukkan bahwa terdapat beberapa kelebihan ppenggunaan Instagram sebagai media pembelajaran. Pertama, santri dapat mengaplikasikan pembelajaran maharah al kitabah dimana saja dan kapan saja karena penggunaan tidak terbatas waktu dan tempat. Kedua, santri akan belajar secara perlahan melalui respon dari para follower yang membenarkan. Ketiga, santri memanfaatkan Instagram sebagai media pembelajaran. Keempat, menjadikan santri lebih aktif, kreatif dan inovatif tidak hanya di dalam kelas namun juga diluar kelas. Kelima, menjadikan pembelajaran lebih bervariasi dengan membidik kecenderungan santri pada masa kini. Keenam, santri lebih mudah mengakses materi pembelajaram.

\section{Kekurangan Instagram sebagai media pembelajaran maharah al kitabah}

Adapun kekurangan Instagram sebagai media pembelajaran berdasarkan kesimpulan hasil angket adalah sebagai berikut: pertama, santri membutuhkan modal untuk layanan koneksi internet untuk mengakses fitur-fitur yang ada di Instagram. Jika tidak tersambung atau terhubung dengan jaringan internet, maka santri tidak bisa mengaplikasikan penggunaan Instagram sebagai media pembelajaran. Kedua, pengajar tidak bisa mengontrol secara intensif dari penggunaan media Instagram dimana beberapa hal negatif juga merupakandampak dari penggunaan media sosial. Ketiga, Santri bukan pengguna aktif media sosial sehingga membutuhkan pengetahuan media Instagram dan penggunaannya. Keempat, pembelajaran secara tidak langsung. Kelima, Media tersebut tidak fokus menyediakan tentang pembelajaran bahasa Arab saja, akan tetapi banyak foto atau video bukan konten berbahasa Arab.

\section{Kesimpulan}

Pembelajaran maharah al kitabah perlu adanya inovasi, seiring dengan perkembangan zaman society 5.0 khususnya kalangan anak muda yang hampir tidak lepas dengan smartphone dan mobile. Insragram merupakan media sosial yang sangat cocok dan mendukung santri untuk mengeksplorasi ide-ide dalam bentuk tulisan sehingga membentuk kebiasaan menulis kreatif dan menarik. Hal ini didukung oleh tampilan fitur-fitur Instagram yang lebih menarik dan efektif untuk pembelajaran maharah al kitabah dibandingkan media sosial lainnya seperti Facebook, Whatsapp, dan lain sebagainya. seluruh santri pondok pesantren Al Azhar Malang yang telah mengisi angket di google form setuju dengan penggunaan Instagram dalam pembelajaran maharah al kitabah karena penggunaannya yang tidak terbatas waktu dan tepat, mudah diakses, ketersediaan fitur-fiturnya yang sangat menarik dan memotivasi santri untuk aktif, kreatif dan inovatif ketika mengerjakan tugas.

Penelitian ini memiliki keterbatasan, penggunaan Instagram dalam pembelajaran ini hanya bersifat penugasan yang dilaksanakan diluar kelas, karena santri tidak diperbolehkan menggunakan gadget di dalam kelas. Dan menyarankan 
agar pembelajaran maharah al kitabah harus dilakukan inovasi dan media yang sering digunakan para santri agar pembelajaran tidak monoton. Dan santri harus bisa memanfaatkan Instagram dengan bijak dalam belajar bahasa Arab dengan banyak memfollow akun-akun yang menyediakan pembelajaran bahasa.

\section{Referensi}

Ahmadi, A. (2014). Optimalisasi Pemanfaatan Laboratorium Bahasa dalam Meningkatkan Pembelajaran Bahasa Arab. Al-Ta'rib: Jurnal Ilmiah Program Studi Pendidikan Bahasa Arab IAIN Palangka Raya, 2(1), 67-74. https://doi.org/10.23971/altarib.v2i1.1534

Albantani, A. M. (2019). Social Media as Alternative Media for Arabic Teaching in Digital Era. ALSINATUNA, 4(2), 148-161. https://doi.org/10.28918/alsinatuna.v4i2.2043

Albantani, A., Madkur, A., \& Rozak, A. (2020, May 25). Social Media in Classroom: The Use of Facebook in Foreign Language Learning. Proceedings of the 2nd International Conference on Quran and Hadith Studies Information Technology and Media in Conjunction with the 1st International Conference on Islam, Science and Technology, ICONQUHAS \& ICONIST, Bandung, October 2-4, 2018, Indonesia. http://dx.doi.org/10.4108/eai.2-10-2018.2295511

Anggraeni, C. W. (2017). Students Perspectives toward the Use of Instagram in Writing Class. English Language and Literature International Conference (ELLiC) Proceedings, 1(0), 68-74.

Aspari, A. (2016). Media Sosial Sebagai Media Pembelajaran Bahasa Pada Masyarakat Modern. Prosiding, Simposium Nasional Ilmu Pengetahuan Dan Teknologi (SIMNASIPTEK).

Deguchi, A., Hirai, C., Matsuoka, H., Nakano, T., Oshima, K., Tai, M., \& Tani, S. (2020). What Is Society 5.0? In Society 5.0: A People-centric Super-smart Society (pp. 1-23). Springer. https://doi.org/10.1007/978-981-15-2989-4_1

Haniah, H. (2014). Pemanfaatan Teknologi Informasi dalam Mengatasi Masalah Belajar Bahasa Arab. Al-Ta'rib: Jurnal Ilmiah Program Studi Pendidikan Bahasa Arab Palangka Raya, 2(1). https://doi.org/10.23971/altarib.v2i1.588

Hidayat, A. (n.d.). Demokrasi Digital Era Media Sosial. detiknews. Retrieved February 27, 2020, from https://news.detik.com/kolom/d4569835/demokrasi-digital-era-media-sosial

Khalitova, L., \& Gimaletdinova, G. (2016). Mobile Technologies in Teaching English as A Foreign Language in Higher Education: A Case Study of Using Mobile Application Instagram. 6155-6161. https://doi.org/10.21125/iceri.2016.0395

Linur, R., \& Mubarak, M. R. (2020). Facebook sebagai Alternatif Media Pengembangan Maharah Kitabah. Jurnal Naskhi: Jurnal Kajian Pendidikan Dan Bahasa Arab, 2(1), 8-18. 
Mc Dermott, G. (2013). The role of social media in foreign language teaching: A case study for French. Recherche et Pratiques Pédagogiques En Langues de Spécialité. Cahiers de l'Apliut, Vol. XXXII $N^{\circ} 2,141-157$. https://doi.org/10.4000/apliut.4234

Miles, M. B., \& Huberman, M. (2009). Analisis Data Kualitatif. UI Press.

Mubarak, M. R., Wahdah, N., Ilmiani, A. M., \& Hamidah, H. (2020). Penggunaan VLOG dalam Pembelajaran Maharah Kalam. Al Mi'yar: Jurnal Ilmiah Pembelajaran Bahasa Arab dan Kebahasaaraban, 3(1), 109-126. https://doi.org/10.35931/am.v3i1.209

Munir. (2016). Perencanaan Sistem Pengajaran Bahasa Arab. Prenada Media.

Romney, M., \& Johnson, R. G. (2020). Show me a story: Narrative, image, and audience engagement on sports network Instagram accounts. Information, $\begin{array}{llll}\text { Communication } \quad \& \quad \text { Society, } & \text { 23(1), }\end{array}$ https://doi.org/10.1080/1369118X.2018.1486868

Sa'diyah, H. (2019). Strategi Pembelajaran Bahasa Arab Penuh Inovasi dan kontemporer (D. Hilmi, Ed.; Vol. 1). Nusantara Global Press.

Syukriya, A. U. (2019). Implementasi PjBL dengan Media Instagram pada Keterampilan Menulis Bahasa Arab di SMA Islam P.B Soedirman 1 Bekasi. Prosiding Konfererensi Nasional Bahasa Arab, 5(5), 389-399.

\section{Copyright Notice}

Authors retain copyright and grant the journal right of first publication with the work simultaneously licensed under a Creative Commons Attribution 4.0 International License that allows others to share the work with an acknowledgement of the work's authorship and initial publication in this journal. 
HALAMAN INI SENGAJA DIKOSONGKAN 